\title{
原著子宮内膜搔爬術におけるハリ麻酔効果(第 2 報)
}

\author{
亀井順二* 松原一太島 清 \\ 可世木 辰夫
}

要旨 前回に続き子宮内膜搔爬のハリ麻酔効果を検討した。

今回スコア表を改善し，より実用的なものとした。

症例を413例に增やしたが，CMI test 馬島変法による分類「自律神 経失調型」は効果が悪かった。

術者の手術手技と効果差を検討したが，有効率の高い術者で63\%， 低い術者で14\%～26\%と，有効率に差が認められた。

痛みの訴之の客観化を目的に，手掌〜前腕間の皮膚電位差測定を行 い痛みとの関連を観察したが，ハリ麻酔無効群に高い電位が出現する 傾向は認められたが，評価法としてはさらに検討を要すると思われる。

\section{I はじめに}

われわれは，第一報として子宮内膜搔爬術にお けるハリ麻酔効果の個人差を, CMI test馬島変法 を用いて検討し，さらに独自の効果判定の試みに ついても検討した。

その結果は患者をCMI test馬島変法にて心身面 から分類した場合，「自律神経失調型」に効果が悪 いことを報告しだ”。

今回さらに症例を増やすとともに，痛みに影響 を与える要因である医師の手術手技と，八リ麻酔 の効果差について検討した。

また痛みの客観的な把握法として，手掌部の電 位の測定を試みた。

さらに効果判定の問題で, 従来より使用してい たスコア表をより簡便で有意義なものに改善した。

*Junji KAMEI 可世木病院

共同研究者：Kazuta Matsubara, Kiyoshi Oshima, Tatsuo KASEKI 可世木病院

Key Words：子宮内膜搔爬術, 八リ麻酔, CMI test馬島変 法, GSR

\section{II 症例と術式}

今回の症例は，昭和 57 年 12 月 60 年 12 月までに， ハリ麻酔で子宮内膜搔爬術を行った413例である。 その分類は，不妊症における試験搔爬406例・不正 出血による子宮内膜搔爬 2 例·子宮内容除去術 5 例 であった。

ハリ麻酔の方法は，中国針 2 インチ 28 号を用い， 使用穴は足三里・三陰交を主穴とし，一部症例に 㓌陵泉・子宮穴などを補助的に用いた。

針を刺入後，充分な得気を確認し，通電機(ノイ ロメーターNAJ)に接続した。

そして約10分〜30分の誘導の後，手後を開始し た。

\section{III 効 果判 定}

1) スコア評価值

効果判定は，2つの方法で行った。

まず術中の患者の表情など 7 つの項目を観察し， その程度によって 0 〜 点までの点数をつけた。

(Table 1)

これをスコア評価值と呼び，前回報告で使用し ていたものを今回改良した。つまり「汗」と「淚」, 
Table 1 効果判定(亀井・可世木スコア表)

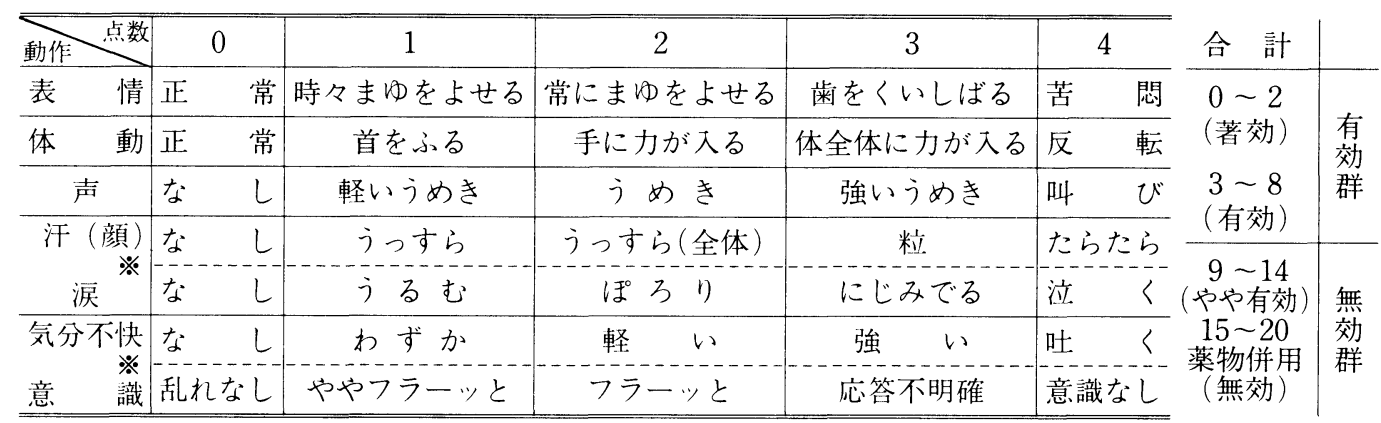

※揃目は1段上の点，不揃は高い方の点をとる。

「気分不快」と「意識」については，まず独立して点 数をつけ，集計の時たとえば”汗が粒”。“涙がにじ みでる゙というように同じところに並んでいれば, 効果判定としての点数としては 1 つ早 4 点とす る。

まだ汗が粘”で淚がうるむ”という場合，高い 方の゙汗”の 3 点を取るというようにした。つまり 「汗」と「涙」、「気分不快」と「意識」を効果判定の点 数上一つのグループにした。

そして各項目の合計点が，０～20点になるよう にし，臨床的に応用した結果， 0 〜 点を「著効」, $3 \sim 8$ 点を「有効」，9－14点を「やや有効」，15〜 20点を「無効」とした。

それらのうち，「著効」「有効」例を痛みの表現 が少いと考え, 八リ麻酔有効群とした。

2) アンケート方式

効果判定の 2 つ目の方法として, 術後にアンケ 一トをとり，手術中の痛さを「全く無痛」「軽い痛 み」・「やや強い痛み」・「かなりの痛み」の 4 段階に 分けて答えてもらった。

そして「全く無痛」〜「やや強い痛み」までをハリ 麻酔有効群とした(Table 2)。

なお八リ麻酔のみにて手術を行うことを目的と し, 麻酔薬を少量でも補助的に用いた症例や，術 後の気分不快や痛みのため, $\mathrm{O}_{2}$ 吸入や鎮痛剂を使 用した症例は，画効果判定とも全て無効とした。

\section{CMl test 馬島変法との関連}

前回報告で, CMI test 馬島変法とハリ麻酔効果 の関連を報告したが, 今回さらに症例数を増やし
Table 2 効果判定 2

(術後のアンケート回答)

1.「全〈無痛」

2.「軽い痛みがあつた」 有効群

3.「やや強い痛みがあった」

4.「かなり痛かった」

5. 薬物併用

無効群

た結果，やはり前回同様「自律神経失調型」はハリ 麻酔効果が悪かった(Fig. 1)。

\section{V 術者別効果}

CMI test とハリ麻酔効果の関連では，ハリ麻酔 効果の個人差を患者の心身面から観察したが，八 リ麻酔効果に影響を与えるもう 1 つ要因として, 術者(医師)の手術手技の問題がある。

当院は 5 人の医師が内膜搔爬を行っているが, 有効率の高い術者は63\%, 低い術者はアンケート 方式で $26 \%$ ，スコア評価值で14\%と有効率に差が あった（3例のみの $\mathrm{E}$ 医師は除く）(Fig. 2)。

\section{VI 皮后電位差測定}

次にわれわれの 2 つの効果判定法に加え, さら に痛みの訴之の客観化を目的とし，手掌と前腕の 皮膚電位差を測定した。

精神的な興奮によって, 皮膚通電抵抗が低下す る現象は, 電流性皮膚反射または, 皮虙電気反射 (Galvanic Skin Reflex, 以下 GSR)として知られ ている

そこでGSR を目標に，手術中の電位差を测定し， 


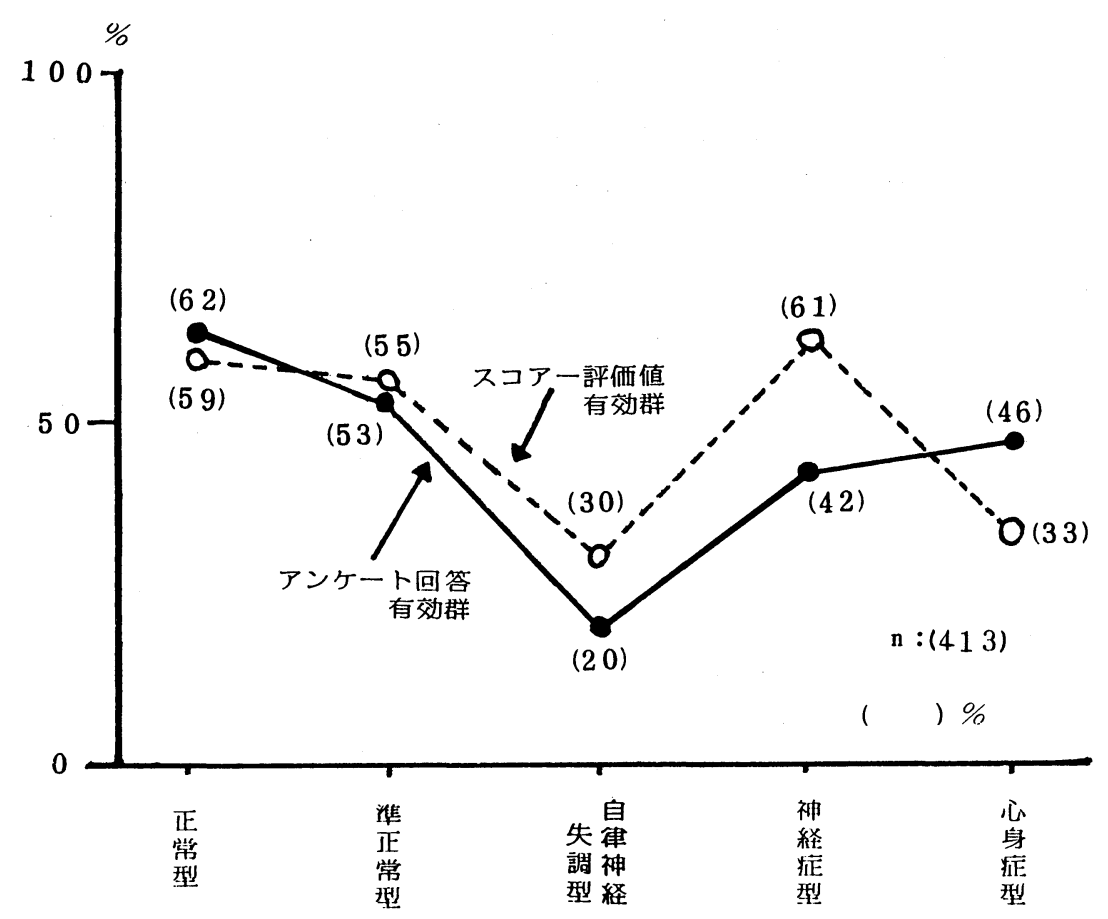

Fig. 1 アンケート回答とスコア評価值との有効率の比較

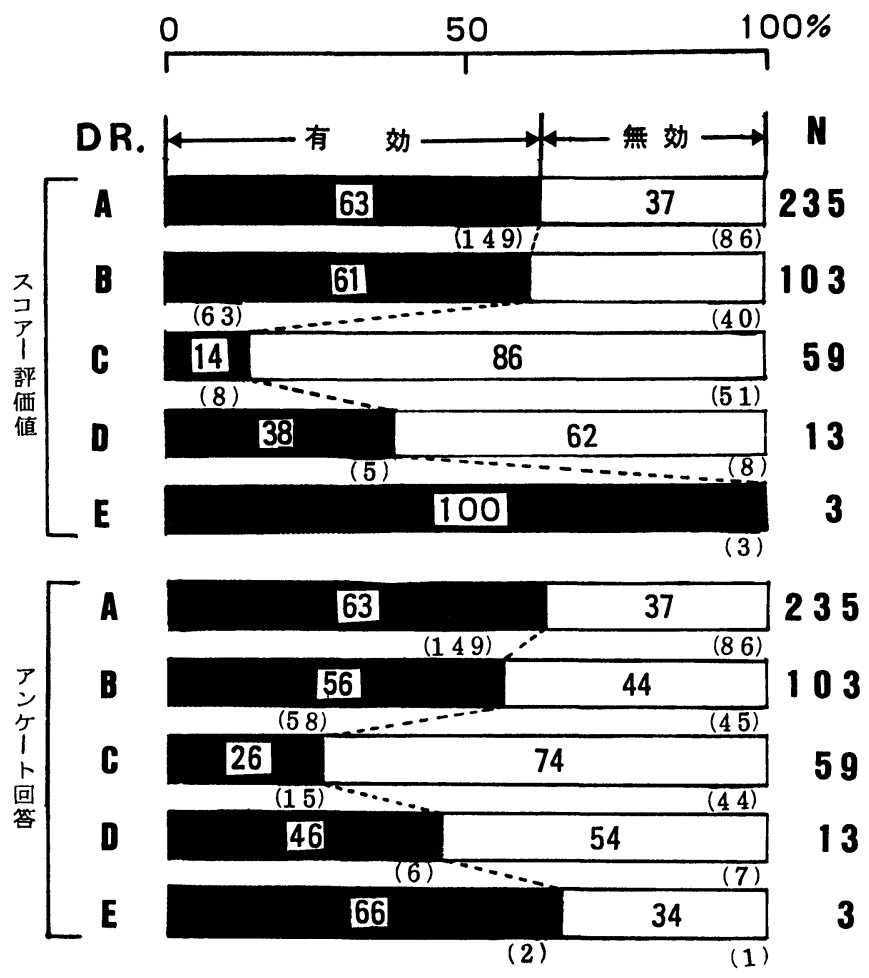

Fig. 2 術者別による効果比較 
出現した電位と痛みの強さとの関連を検討した。

GSRの測定には，皮虐通電抵抗測定法と皮膚電 位を測定する電位法があるが，この電位法を目的 に行った。

通電法は，皮虐から微弱な電流を流して記録し， 外部から被検者に刺激を与えると，皮膚の見かけ の電気抵抗の一時的な減少による電流值の増加を 観察するものである。

電位法は，電流を通じることなく，皮膚の 2 力 所に電極をつけ，その電位変動をみる方法である ${ }^{3)}$ 。 今回われわれが行った測定条件は，フクダ DU $3 \mathrm{~S}$ 心電計と心電困記録用紙を用い，手掌と前腕 中央に電極を置き， $0 \sim 8 \mathrm{mV}$ の電位を測定した

\section{(Fig. 3)。}

ただし現段階では，GSRの測定という用語は用 いず，手掌〜前腕間の皮膚電位差測定と呼び報告 する。

\section{1) 手術操作との関連}

今回測定を行った症例は30例で，Fig. 4ばクス コの胵鏡を入れる゙など術中の各操作で出現した電位 の平均值で，グラフ中において上はスコア評価值,
下はアンケート方式による効果判定である。

その中で丸実線 $(\bigcirc-○)$ はハリ麻酔有効群, バツ点線 $(\times \cdots-\cdots \times)$ は無効群である。

全体的にみて無効群の方が, 各操作時に高電位 が出現する傾向がみられた。

2) 各症例の出現電位值と効果判定法

次の黒丸は手術中の前述した各操作時に出現し た電位の各症例ごとの平均值である(Fig. 5)。

グラフ中，上の 0 １4はスコア評価值の点数で 高得点ほど痛かっだということであり，下は「無 痛」〜「かなりの痛み」までの患者のアンケート方式 と電位との関連である。

この結果からは, 痛みの強さと電位差の変化に 関連は認められなかった。

これらは今回目的としたGSRが，性格・年齢や 催眠，または痛くないという暗示などによって出現 状態が変化するとされ゙われわれが測定した皮膚電 位差も，必ずしも手術の痛みによる反応としての 出現だけでなく，各症例の個体差などの要因も関 係していると思われる。

測定部位：手掌～前腕部

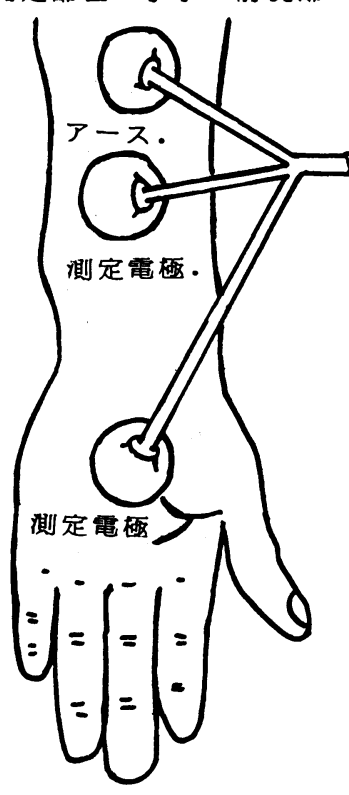

Fig. 3 皮虐電位差測定

測定時間: 手術直前 手術直後

測定条件：速度、 $10 \mathrm{~mm}$ 己 $25 \mathrm{~mm} / \mathrm{sec}$.

$0.5 \mathrm{~cm} 1 \mathrm{mV}$ とて

$8.0 \mathrm{mV}$ まで測定 

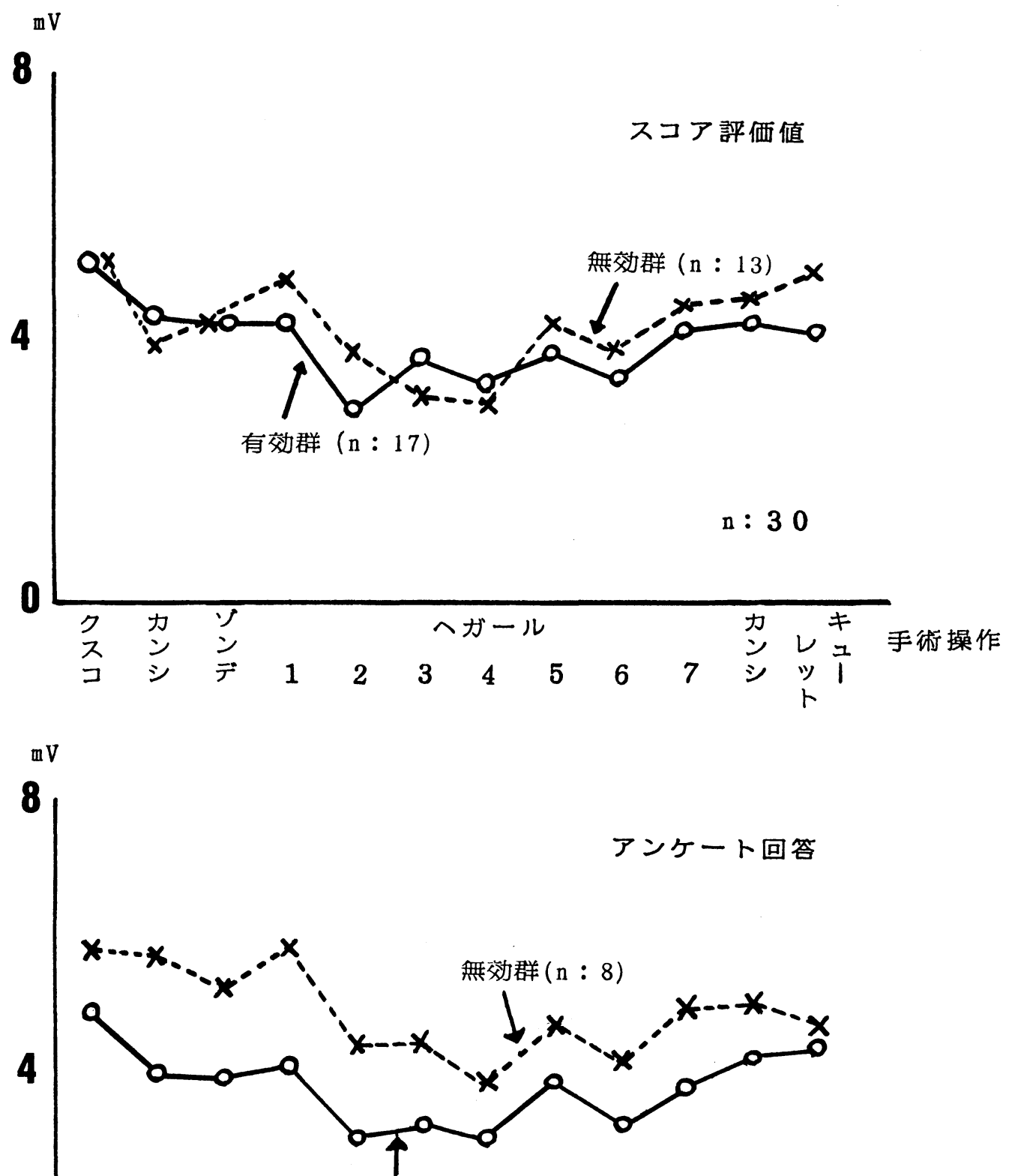

有効群 $(\mathrm{n}: 22)$

n: 30

0

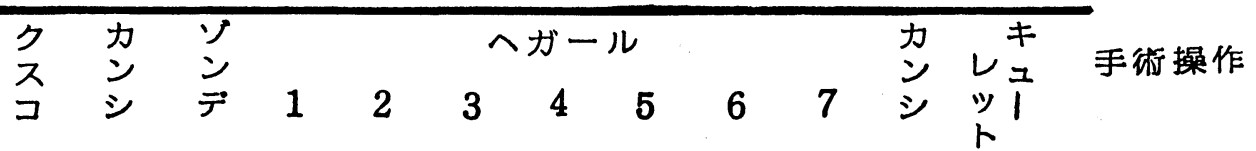

Fig. 4 有効群無効群の平均電位と手術操作との関連 

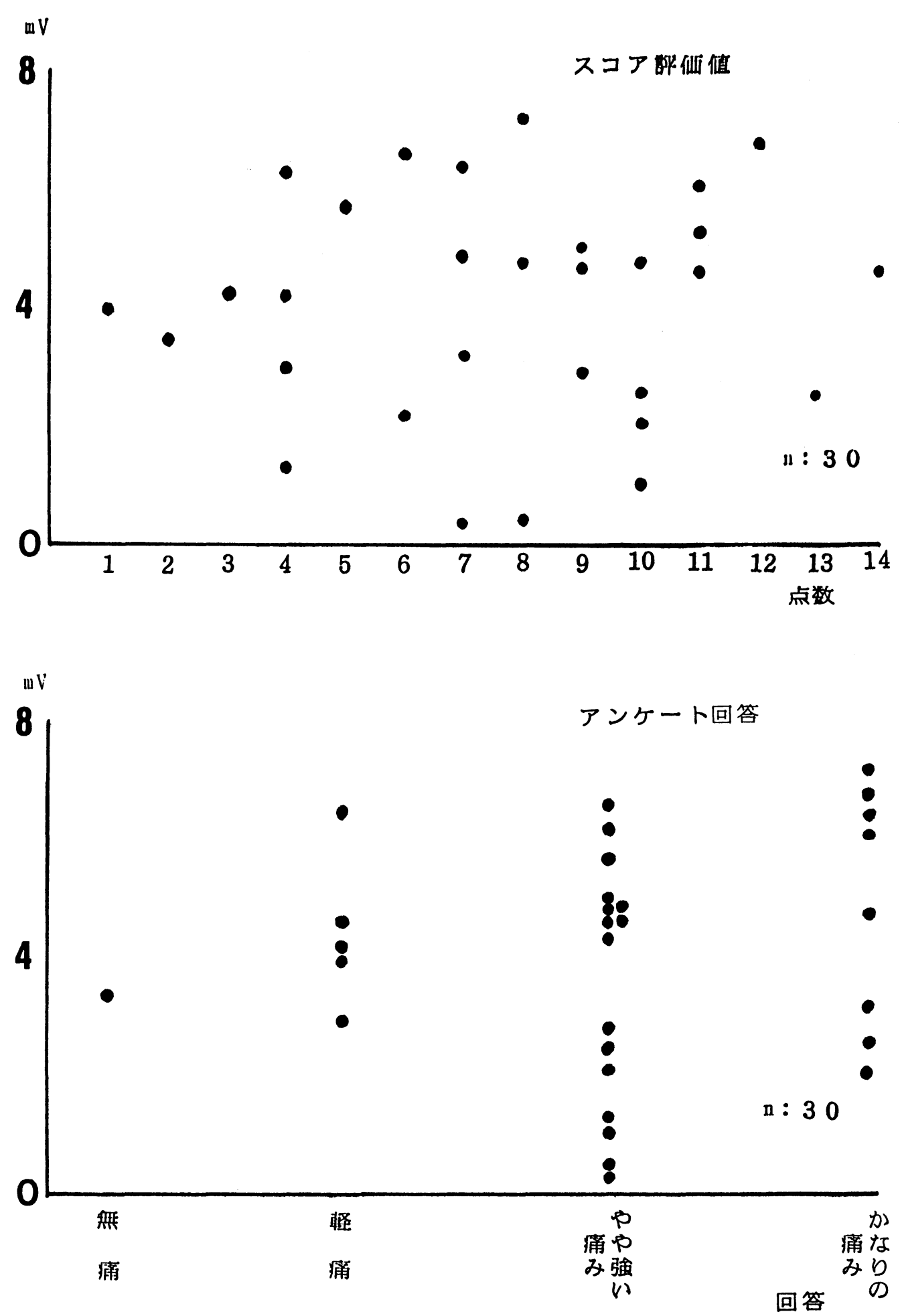

Fig. 5 操作中の電位平均値と評価法との相関 


\section{VII 結 語}

1) 効果判定：前回アンケート方式とスコア評 価值の 2 つの効果判定の有効率に多少の差があっ たため, スコア表を改良した結果, 有効率は近似 し効果判定表としての実用性を確認した。

2） CMI test 馬島変法との関連：症例数を増や しても「自律神経失調型」は効果が悪かった。

3）術者別効果：術者間のハリ麻酔有効率に差 があり，ハリ麻酔の成功は術者の手術手技に影響 されることを確認した。

4）皮膚電位差測定：手掌と前腕間の皮膚電位 差測定を行い痛みとの関連を観察したがハリ麻酔 無効群は有効群に比べ高い電位が出現する傾向は みられたが，痛みの強さと電位の大きさとの間に 相関は認められなかった。

なお本研究を行うにあたり御指導をいただいた，可 世木病院 - 加藤正三先生 - 池田淳先生, 愛知学院大学 歯学部教授・小長谷九一郎先生, その他御協力いただ いた方々に深謝する次第である。

\section{参考文献}

1）亀井順二ほか：子宮内膜搔爬術におけるハリ麻 醉効果と CMI テスト馬島変法との関連について, 全日本銊尒学会誌 36(2);125～129. (1986)

2）真島英信：生理学，16，文光堂，東京（1975）, 463.

3）新美良純編：皮虚電気反射, 医歯薬出版, 東京 (1960), 14 15.

（干460 名古屋市中区栄四丁目16-16 可世木病院） 


\title{
Effect of Acupuncture ANESTHESIA in Intrauterine Curettage (Part II)
}

\author{
Junji Kamei, et al. \\ Kaseki gyin. \& obst Hospital
}

(1) Some improvements were made in the score table used for evaluation of effectiveness in the previous studies.

(2) The number of the cases evaluated was incresed.

(3) The difference in effectiveness of acupuncture anaesthesia and the doctors' skill of operation, the factor which influences painfulness, were also examined.

(4) The measurement of palm-forearm skin potential was employed as an objective evaluation of pain.

\section{METHODS}

Acupuncture anaesthesia was undertaken using Neurometer NAJ. Induction was done through Chinese needles ( 2 inch no.28) inserted on Zusanli and Sanyinjiao for 20 minutes.

The evaluation was done on 413 cases which underwent intrauterine curettage under acupuncture anaesthesia in 1982-1985.

The evaluation of the effectiveness was carried out in two ways : (1) using scores based on the observation of patient's expression of the face and other signs, and (2) subjective evaluation (questionnaire) during the operation.

The skin potential was measured between the electrodes applied to the palm and the forearm using ECG (Fukuda-DU3S).

The relationship was examined between the potential and pain during the operation was examined. $(10 \mathrm{~mm}-25 \mathrm{~mm} / \mathrm{sec}, 0-8 \mathrm{mmV})$

RESULT

(1) As a result of the improvement in the score table, the effectiveness rate obtained from the questionnaire and that from the score table were close enough to conough to confirm its utility.

(2) Less effectiveness of acupuncture anaesthesia was obtained in the patients classified into the "type of unbalanced autonomic nervous system" according to the classification of the CMI test modified by Majima. This result was coincide with the previous report.

(3) Among five doctors, one obtained the bèst effective rate of $63 \%$, and others got those of $14-26 \%$.

(4) In the measurement of the potential between the palm and the forearm, values of $0.1-8.0 \mathrm{mV}$ appeared. Although there was a tendency that the severer the pain was, the higher the potential was, the actual value of this measurement as a rating method is to be examined. 